\title{
Whistleblowing at Health Canada: Chopra speaks out
}

\author{
Corrupt to the Core: Memoirs of a Health \\ Canada Whistleblower \\ Dr. Shiv Chopra \\ KO $\Sigma$ Publishing; 2008 \\ 200 pp $\$ 25$
}

I n 1998, Dr. Shiv Chopra and two colleagues testified to a Senate Committee that Health Canada managers had pressured them to release suspect veterinary drugs into the food chain without the evidence of safety required by the Food and Drugs Act.

These allegations shocked the public, triggered headlines around the world and ultimately led to the rejection of one particular drug (bovine growth hormone) in Canada, Europe and most developed countries - even though it had been already approved in the USA. The scientists' testimony also raised serious questions about the effectiveness of Health Canada as a regulator and its relationship with the drug industry.

Chopra's first lesson regarding the mindset of the bureaucracy came in 1974, during an interview for a promotion:

... a member of the Selection Board, Norman Stevenson, asked me as follows: "Suppose you are selected for this post, whom would you consider to be your client?" I replied: "The public, of course." "No, it is the industry," said Stephenson. I begged to disagree with him. "From whom do you draw your mandate?" asked Scott as a follow-up question. "From the Food and Drugs Act, passed by the Canadian Parliament on behalf of the public," I replied. I hate to think that the reason I failed to obtain this post was due to my answers before this Public Service Commission Selection Board.

Chopra chronicles intrigue, manipulation and deception as Health Canada managers - at the behest of their political bosses — worked to please their drug company clients. Among other things, he accuses management of:

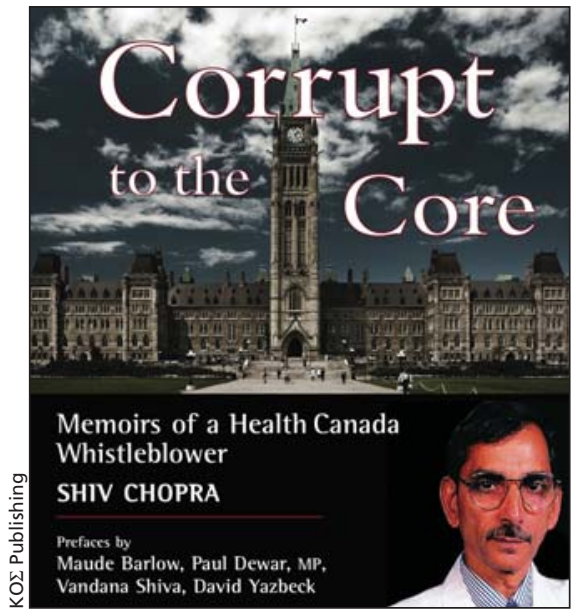

- Ignoring a central tenet of the Food and Drugs Act requiring manufacturers to provide evidence of safety before approval

- Ignoring and sidelining scientists who refuse to approve drugs without evidence of safety

- Approving veterinary drugs containing carcinogens and hormones that have detrimental health effects

- Refusing to revisit approved drugs after new evidence showed they were unsafe

- Ignoring or manipulating scientists' reports on certain drugs

- Forbidding scientists to speak to anyone about their work.

By refusing to collude with what they saw as misconduct within their own department, Chopra, Dr. Margaret Hayden and Dr. Gerard Lambert joined the ranks of courageous Canadians who have sought to protect the public interest by performing their jobs with integrity, even when doing so brought them into conflict with their bosses.

Like most other whistleblowers, they have paid a high price for their actions: in June 2004 all three were fired by Health Canada and they have spent the past four years in hearings before the Public Service Labour Relations Board as their union battles to have them reinstated. The best outcome that they can hope for is to be restored to jobs in a department that seemingly doesn't want them as employees.

In Canada, there are very few laws to protect whistleblowers, and none are very effective. As a result, most Canadian whistleblowers suffer from reprisals orchestrated by their own bosses, aimed at silencing, discrediting and punishing them. Most lose their careers, their health and even their families as a result of the intolerable stress placed upon them. Chopra's memoir is important because it portrays the typical plight of someone in this position and the serious risks to the public that can arise when there is no protection for such brave people.

Health Canada has a vital role to play in our society, yet it is known to be secretive - the department received the Canadian Association of Journalist's 2004 "Code of Silence" award and this is not the first time it has been accused of taking reprisals against whistleblowers. ${ }^{1}$ Chopra's book is a must read for anyone who wants to understand how politics and corporate influence, science and the law interacted within a troubled bureaucracy and how powerful forces can betray the public interest by overwhelming individual conscience.

\section{David Hutton BSc}

Executive Director

Federal Accountability Initiative for Reform (FAIR)

Ottawa, Ont.

FAIR is a Canadian charity devoted to "protecting whistleblowers who protect the public interest" (http://fairwhistleblower.ca).

\section{REFERENCE}

1. Nikiforuk A. A public tarring in Saudi Canada. The Toronto Star 2009 Jun 28;Sect A:19. 